\title{
Diversity of Monogenoidea parasitizing scombrid fishes from Rio de Janeiro coast, Brazil
}

\author{
Marcia C. N. Justo* and Anna Kohn \\ Laboratório de Helmintos Parasitos de Peixes, Instituto Oswaldo Cruz, Fiocruz, Av. Brasil, 4365, Rio de Janeiro, Brazil \\ Corresponding author. E-mail: marciajusto@ioc.fiocruz.br
}

\begin{abstract}
Eleven known species of Monogenoidea were found parasitizing six different species of scombrid fishes collected from Rio de Janeiro coast, Southwestern Atlantic Ocean: Capsala biparasitica, Capsala katsuwoni, Capsala notosinense, Nasicola brasiliensis, Nasicola klawei, Allopseudaxinoides euthynni, Sibitrema poonui, Hexostoma albsmithi, Hexostoma euthynni, Hexostoma keokeo and Hexostoma sibi. Katsuwonus pelamis is reported as a new host to A. euthynni and Thunnus obesus to H. albsmithi. Capsala notosinense, A. euthynni, H. albsmithi and $H$. sibi are referred for the first time in Brazil, Southwestern Atlantic Ocean. Morphological and morphometric features are presented for each species.
\end{abstract}

Key words: Axinidae, Capsalidae, Hexostomatidae, Gastrocotylidae, Monogenoidea, Scombridae

\section{INTRODUCTION}

During a survey of helminth parasites of Scombridae from the coast of the Rio de Janeiro, Brazil, Southwestern Atlantic Ocean, species of Monogenoidea were found parasitizing Auxis thazard (Lacepède, 180o), Euthynnus alletteratus (Rafinesque, 1810), Katsuwonus pelamis (Linnaeus, 1758), Thunnus albacares (Bonnaterre, 1788), Thunnus atlanticus (Lesson, 1831) and Thunnus obesus (Lowe, 1839). These fishes support very important commercial and recreational fisheries as well as substantial artisanal fisheries throughout the tropical and temperate waters of the world (Collette and Nauen 1983). Considering that Brazil has a large canned-fish industry, these species are very important economically.

In South America monogenean parasites of scombrid fishes are represented by 16 genera (see Cohen et al. 2013). Research on monogenoidean parasites of scombrid fishes from Brazil had been conducted by Abdallah et al. (2002), Alves and Luque (2006), Kohn and Justo (2006), Kohn et al. (2003), Kohn et al. (2004), Mogrovejo and Santos (2002), Mogrovejo et al. (2004), Oliva et al.
(2008), Price (1938), Rego and Santos (1983), Rohde (1986), Rohde and Hayward (1999) and Rohde and Watson (1985). The aim of this study is to contribute to the increase of the knowledge and expansion of the geographical distribution of monogenoidean parasites in different species of Scombridae in the area of the Southwestern Atlantic Ocean.

\section{MATERIAL AND METHODS}

A total of 230 specimens of scombrid fishes were examined between January 2004 to April 2007: 20 Auxis thazard (29-54 cm in total body length and $0.65-2.5 \mathrm{~kg}$ in weight), 31 Euthynnus alletteratus $(27-71 \mathrm{~cm}$ in total body length and $0.50-4.0 \mathrm{~kg}$ in weight), 61 Katsuwonus pelamis $(26-73 \mathrm{~cm}$ in total body length and $1.0-9.0 \mathrm{~kg}$ in weight), 38 Thunnus albacares (34-76 cm in total body length and $0.55-7.8 \mathrm{~kg}$ in weight), 45 Thunnus atlanticus (38-61 cm in total body length and $1.2-5.5 \mathrm{~kg}$ in weight) and 35 Thunnus obesus (39-67 cm in total body length and $1.2-6.3 \mathrm{~kg}$ in weight).

The fishes were obtained by local fishermen from the coastal zone of the state of Rio de Janeiro, Brazil $\left(22^{\circ} 52^{\prime} 46^{\prime \prime} \mathrm{S}, 042^{\circ} 01^{\prime} \mathrm{O} 7^{\prime \prime} \mathrm{W}\right)$. The parasites collected were fixed under light cover-glass pressure in $5 \%$ formaldehyde, stained with Langeron's alcoholic-acid carmine, dehydrated in an ethyl alcohol series, cleared in beechwood creosote and mounted in Canada balsam as permanent slides. Measurements are in micrometers, unless otherwise specified, with the mean in parentheses followed by the number of specimens measured in brackets, where applicable. The material studied was deposited in the Helminthological Collection of the "Instituto Oswaldo Cruz" (CHIOC), Rio de Janeiro, Brazil.

\section{RESULTS AND DISCUSSION}

Eleven cosmopolitan species of four families of monogenoideans, already referred in different fish and oceans were found. Allopseudaxinoides euthynni 
Yamaguti, 1966 (Axinidae); Capsala biparasitica (Goto, 1894), Capsala katsuwoni (Ishii, 1936), Capsala notosinense (Mamaev, 1968), Hexostoma albsmithi Dollfus, 1962, Nasicola brasiliensis Kohn, Baptista-Farias, Santos \& Gibson, 2004, Nasicola klawei (Stunkard, 1962) (Capsalidae); Hexostoma euthynni Meserve, 1938, Hexostoma keokeo Yamaguti, 1968, Hexostoma sibi Yamaguti, 1968 (Hexostomatidae) and Sibitrema poonui Yamaguti, 1966 (Gastrocotylidae).

The most prevalent species were $N$. klawei parasitizing T. albacares $(81.6 \%)$ and $N$. brasiliensis parasitizing T. obesus $(77.1 \%)$ and T. atlanticus (68.9\%). New host records are reported: K. pelamis to A. euthynni and T. obesus to $H$. albsmithi. C. notosinense, A. euthynni, H. albsmithi and $H$. sibi are reported for the first time in the Rio de Janeiro coast, Southwestern Atlantic Ocean.

\section{Lists of parasite species}

Phylum Platyhelminthes Gegenbaur, 1859

Class Monogenoidea Bychowsky, 1937

Subclass Polyonchoinea Bychowsky, 1937

Family Capsalidae Baird, 1853

Subfamily Capsalinae Baird, 1853

Capsala Bosc, 1811

Capsala biparasitica (Goto, 1894) Price, 1938

Synonyms: Caballerocotyla abidjani Bussiéras \& Baudin-Laurencin, 1970; Caballerocotyla neothunni Yamaguti, 1968

Hosts: T. albacares, T. atlanticus and T. obesus

Site: Gills

Prevalence: T. albacares (21.1\%); T. atlanticus (4.4\%); T. obesus $(5.7 \%)$

Mean intensity: T. albacares $(2.0 \pm 1.23)$; T. atlanticus (0.07 \pm 0.07$)$; T. obesus $(1.50 \pm 0.98)$

Material studied: CHIOC 36612 a-c, 36613, 37976, 37977

Main measurements (based on six adults and one immature specimens). Adult specimens: Body elongate, 8.0-9.4 (8.7) $\mathrm{mm} \times 3.6-4.8(4.4) \mathrm{mm}$ with two pairs of eye spots; single longitudinal row of dorsolateral spines, 57-73 on right side and 57-74 on left side in number, with 9-12 cuspids each. Cephalic suckers 600-800 (703) $\times$ 1.00-1.04 $(1.03) \mathrm{mm}$, concave ventrally. Haptor sessile $2.5-3.0(2.7) \mathrm{mm} \times 2.5-2.8$ (2.6) $\mathrm{mm}$, surrounded by delicate marginal membrane $140-150$ wide. One pair of anchors, 65-135 (84) long. Pharynx muscular, composed of two unequal bulbs, the posterior smaller than the anterior, 780-1.04 (900) total length by 920-1.16 (1.03) largest wide. Mouth opening ventrally at anterior end of pharynx. Testes about 6o, rounded, 195-370 (248) $\times$ 100-250 (133), confined to the intercecal field. Seminal receptacle $230 \times 155$. Ovary, 60o-700 (658) × 700-900 (820), immediately pretesticular. Copulatory organ papillate, near to vaginal pore. Egg tetrahedral, with 4 filaments.

Immature specimen: Body elongate, $4.2 \mathrm{~mm} \times 1.3$ $\mathrm{mm}$, with two pairs of eye spots; single longitudinal row of dorsolateral spines, 57 on right side and 62 on left side in number, with 9-12 cuspids each. Cephalic sucker 480 $\times 580$, concave ventrally. Haptor sessile measuring 1.2 $\mathrm{mm} \times 1.1 \mathrm{~mm}$. One pair of anchors measuring 85 long. Pharynx muscular, composed of two unequal bulbs, the posterior smaller than anterior, 440 total length by 420 largest wide. Testes rounded, $75 \times 65$ confined to the intercaecal field. Seminal receptacle $170 \times 95$. Ovary 240 $\times 150$, immediately pretesticular.

Remarks: Chisholm and Whittington (2007) published a revision of the subfamily Capsalinae Baird, 1853 based on literature and examination of type-material and considered only 36 valid species. These authors proposed Caballerocotyla Price, 1960 as synonymous of Capsala Bosc, 1811 and considered Caballerocotyla abidjani and Caballerocotyla neothunni synonymous of Capsala biparasitica. Capsala biparasitica was originally described from a copepod parasitizing T. albacares from Pacific Ocean. In 1960, Price revised Capsalinae and proposed Caballerocotyla for the type species $C$. biparasitica. Yamaguti (1968) described and figured this species as Capsala (Caballerocotyla) biparasitica. Also from the Pacific, Egorova (2000) referred it as Caballerocotyla neothunni. From the Atlantic Ocean, Capsala biparasitica was described as Caballerocotyla abidjani by Bussiéras and Baudin-Laurencin (1970) and by Bussiéras (1972) and as Caballerocotyla neothunni by Kohn and Justo (2006).

\section{Capsala katsuwoni (Ishii, 1936) Price, 1938}

Synonym: Caballerocotyla llewelyni Kohn \& Justo, 2006 [sic]

Hosts: K. pelamis and T. atlanticus (new host record)

Site: Gills

Prevalence: K. pelamis (11.4\%) and T. atlanticus (6.6\%) Mean intensity: K. pelamis $(3.0 \pm 1.64)$; T. atlanticus (one parasitized by one parasite)

Material studied: CHIOC 36611 a-b, 37975

Main measurements (based on one adult specimen parasitizing T. atlanticus): Body 6.2 long, excluding haptor by 6.0 in maximum width. Haptor $1.9 \times 1.7$ $\mathrm{mm}$. Anchors 150 long. Anterior end of body with pair of cephalic lobes and a pair of sucker-like attachment organs, 800 in diameter. Pharynx muscular, 600 in total length by 920 wide. Testes rounded, 37 in number $210 \times$ 150. Few Goto's glands scattered among testes. Ovary subglobular, pre-equatorial, median, 740 by 800 . Seminal receptacle round, 240 by 200 . Vitelline reservoir 300 by 400 , immediately preovarian.

Remarks: Capsala katsuwoni was described by Ishii (1936) as Tristoma katsuwonum from Pacific. This species was included by Price (1938) in the genus Capsala and later in the new genus Caballerocotyla proposed by the 
same author in 1960, but not recognized by Chisholm and Whittington (2007). Kohn and Justo (2006) described the new species Caballerocotyla llewelyni from the Atlantic Ocean, which was considered as synonym of Capsala katsuwoni by Chisholm and Whittington (2007). We present only the main measurements of the specimen from T. atlanticus, which is comparative larger than those found in K. pelamis reported by Ishii (1936), Murugesh (1995) and Kohn and Justo (2006).

Capsala notosinense (Mamaev, 1968) Chisholm \& Whittington 2007

Synonyms: Capsala andhraensis Raju \& Rao, 1980; Caballerocotyla chilensis Pillai \& Pillai, 1976; Capsala katuo Iwata, 1990; Capsala naffari Kardousha, 2002

Hosts: A. thazard and K. pelamis

Site: Gills

Prevalence: A. thazard (20\%); K. pelamis (4.5\%)

Mean intensity: A. thazard $(2.75 \pm 3.01)$; K. pelamis (one parasitized by one parasite)

Material studied: CHIOC $37057 \mathrm{a}-\mathrm{b} ; 37058 \mathrm{a}-\mathrm{h}$.

Main measurements (based on 10 adult specimens parasitizing $A$. thazard): Body oval to elliptical, 2.2-4.2 (3.3) $\mathrm{mm} \times 0.9-2.2$ (1.6) $\mathrm{mm}$. Dorsomarginal body sclerites comprise 2-3 rows of unicuspids sclerites, extending to posterior part of the body, except at to the posterior end near the haptor. Haptor discoid, without papillae, 460-960 (745) $\mathrm{mm} \times 520-920(763) \mathrm{mm}$, with anchors 48-77 (61) long and 14 marginal hooklets. Cephalic ellipsoid lobes, 220-400 (329) × 340-480 (406). Pharynx muscular, 260-480 (386) × 260-440 (353), with a conspicuous equatorial constriction. Testes oval to rounded, 22-40 in number, 88-270 (135) × 60-180 (113). Ovary subglobular, situated at the anterior third of body, 200-370 (274) × 225-400 (308). Vitelline with small follicles in cephalic, cecal, diverticular and testicular regions. Vitelline reservoir, 105-140 (125) × 80-120 (99). Egg tetrahedral.

Remarks: Capsala notosinense was described by Mamaev (1968) from gills from Euthynnus affinis (Cantor, 1850) in South China as Caballerocotyla notosinense. Chisholm and Whittington (2007) considered Capsala andhraensis, Caballerocotyla chilensis, Capsala naffari and Capsala katuo as synonymous of Caballerocotyla notosinense. In this opportunity, Capsala notosinense is reported by the first time in Brazil, Southwestern Atlantic Ocean.

Nasicola (Stunkard, 1962) Yamaguti, 1968

Nasicola brasiliensis Kohn, Baptista-Farias, Santos \& Gibson, 2004

Hosts: T. atlanticus (new host record) and T. obesus

Site: Nasal cavity

Prevalence: T. atlanticus (68.9\%); T. obesus (77.1\%)
Mean intensity: T. atlanticus (3.03 \pm 0.34$) ;$ T. obesus $(2.85 \pm 0.36)$

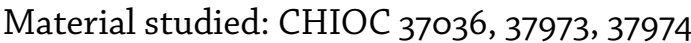

Main measurements (based on three adult specimens from T. atlanticus): Body 11.9-17.5 (15.5) $\mathrm{mm} \times 11.2-15.5$ (13.6) $\mathrm{mm}$. Body surface smooth, except for dorsolateral margins which have outer, irregular row of small spines formed by a broad base, and 1-5 cuspid teeth and inner row of large spines formed by a broad base, and 1-2 cuspid teeth. Haptor 3.2-4.1 (3.6) $\mathrm{mm} \times 3.0-3.9$ (3.5) $\mathrm{mm}$. Cephalic lobe with pair of sucker-like attachment organs, each 590-640 (617) × 660-790 (727). Eye-spots present. Pharynx with postequatorial constriction wider in the anterior portion, with papillae distributed over inner surface, $0.82-1.16$ (0.99) $\mathrm{mm} \times 1.3-1.8$ (1.5) $\mathrm{mm}$ in anterior region, $0.5-0.6(0.5) \mathrm{mm} \times 1.0-1.3(1.2) \mathrm{mm}$ in smaller posterior region. Testes spherical to oval, 90-135 in number, in intercecal field. Cirrus muscular, covered with small papillae. Ovary lobate. Vitellaria formed by many thousands of small follicles, which extend throughout body except in regions of marginal spines, pharynx, gonads, terminal genitalia and attachment organs; vitelline ducts coextensive with intestinal diverticula. Egg tetrahedral, with 4 filaments.

Remarks: This species was originally described by Kohn et al. (2004) from the nasal cavity of T. obesus from Rio de Janeiro coast. The specimens recovered from the new host $T$. atlanticus, are morphometrically similar to those from the type host.

Nasicola klawei (Stunkard, 1962) Yamaguti, 1968

Synonym: Caballerocotyla klawei Stunkard, 1962.

Host: T. albacares

Site: Nasal cavity

Prevalence: $81.6 \%$

Mean intensity: $2.87 \pm 0.37$

Material studied: $\mathrm{CHIOC} 37037$ a-e

Main measurements (based on five adult specimens): Body 9.0-14.2 (13.0) long $\mathrm{mm} \times 9.0-13.0$ (11.0) $\mathrm{mm}$ in maximum width. Row of spines close to margin on each side of body, small, irregularly disposed, with broad base and 2-5 digitiform cusps inner; row of larger spines, on each side of body, with broad base and conical tip with 1-2 digitiform points. Haptor 2.5-3.3 mm (3.0) in diameter, divided by 7 septa forming central polygonal loculus and 7 subtriangular loculi, with 2 similar accessory sclerites and 14 small peripheral marginal hooklets. Cephalic lobe with pair of sucker-like attachment organs, 440$640(540) \times 500-680$ (595). Mouth opening at level of eyespots; pharynx with papillae distributed over inner surface, anterior region 0.70-0.84 (0.77) $\mathrm{mm} \times 1.02-1.44$ (1.23) $\mathrm{mm}$ and posterior region, $0.44-0.60(0.53) \mathrm{mm} \times$ 0.73-1.14 (0.94) mm. Intestinal ceca ramified. Testes 28-33 in number, $140 \times 80$. Cirrus-sac flask-shaped. Vaginal pore opens immediately posterior to genital 
pore. Ovary lobate. Vitelline follicles dispersed throughout body. Egg tetrahedral, with 4 filaments.

Remarks: N. klawei was originally described by Stunkard (1962) as a species of Caballerocotyla Price, 1960, from the nasal cavity of T. albacares (as Neothunnus macropterus) from the Pacific Ocean. In 1968, Yamaguti studied specimens from the same host and from T. obesus (as Parathunnus sibi) from off Hawaii and erected Nasicola to accommodate this species. In the Pacific Ocean it was reported by Egorova (2000) from an unidentified scombrid fish. $N$. klawei was referred in the Atlantic Ocean parasitizing T. albacares by Bussiéras and Baudin-Laurencin (1967, 1973), Bussiéras (1972), Williams Jr. and Bunkley-Williams (1996) and redescribed by Kohn et al. (2004). Ours specimens correspond to the description presented by Kohn et al. (2004) from same host and locality.

Subclass Oligonchoinea Bychowsky, 1937

Family Axinidae Monticelli, 1903

Subfamily Allopseudaxininae Yamaguti, 1963

Allopseudaxinoides Yamaguti, 1965

\section{Allopseudaxinoides euthynni Yamaguti, 1965}

Host: K. pelamis (new host record).

Site: Gills

Prevalence: $4.5 \%$

Mean intensity: Only one specimen was infected

Material studied: $\mathrm{CHIOC}_{37059,37060}$

Main measurements (based on two adult specimens): Body large, 8.2 and $8.6 \mathrm{~mm}$ by 2.6 and $2.8 \mathrm{~mm}$. Haptor unilateral, extending obliquely in the posterior half of the body, with a row of 14-15 clamps and a prominent digitiform caudal appendage which is provided at its blunt end with two pairs of anchors; outer anchor 55 long, inner 25. Clamps 220 and 240 in diameter, constituted by two valves. Rounded anterior end of body, 175 and 205 wide, with two paired oral suckers, 50-51 $\times$ 42; pharynx pyriform, $87 \times 37$. Testes 20 in number, irregular in shape. Genital atrium spherical, 52 and 55 in diameter, with thick wall of radial muscle fibers, armed inside with a corona about 20 spines long and bifid. Genital pore midventral. Ovary $2.04 \mathrm{~mm}$ by $0.40 \mathrm{~mm}$, in midregion of body, with both ends directed backwards. Vitellaria co-extensive with intestine and its branches. Vitelline reservoir Y-shaped. Eggs not visualized.

Remarks: Allopseudaxinoides euthynni was described by Yamaguti (1965) from gills of Euthynnus affinis (as Euthynnus yaito) from Hawaii and redescribed in 1968 in the same host and locality. In this opportunity, it is referred for the first time in Southwestern Atlantic Ocean and in a new host, $K$. pelamis.

Family Gastrocotylidae Price, 1943

Subfamily Gastrocotylinae Sproston, 1946

\section{Sibitrema Yamaguti, 1966}

\section{Sibitrema poonui Yamaguti, 1966}

Synonym: Metapseudaxine ventrosicula Mamaev, 1967

Host: T. obesus

Site: Gills

Prevalence: $5.7 \%$

Mean intensity: Only one specimen was infected

Material studied: $\mathrm{CHIOC}$ 37038, 37039

Main measurements (based on one adult specimen): Total body measuring $9.20 \mathrm{~mm}$ by $1.10 \mathrm{~mm}$ in the region of the ovary and testes. Haptor long, $1.60 \mathrm{~mm} \times 0.54$ $\mathrm{mm}$, with single row of 49 clamps, and terminal appendices with two pairs of anchors of different sizes. Two buccal suckers, $35 \times 30$; pharynx larger than suckers, 54 $\times 38$. Testes rounded, about 70 in number. Vas deferens strongly winding. Muscular genital atrium with single circle of curved terminally bifurcated spines. Ovary tubular. Vitelline follicles small, co-extensive with intestinal branches. Vitelline reservoir Y-shaped. Egg fusiform, $210 \times 90$, with one filament at each pole.

Remarks: Sibitrema poonui was originally described by Yamaguti (1966) from gills of T. albacares (as N. macropterus) and T. obesus (as $P$. sibi) in the Pacific Ocean, Hawaii and redescribed by Rohde (1978) from Cybiosarda elegans (Whitley, 1935) and E. alletteratus from Australia. Bussiéras and Baudin-Laurencin (1973) also referred this species parasitizing T. albacares from Antilles Islands. In Brazil, S. poonui was reported by Kohn et al. (2003) from T. albacares and T. obesus and by Alves and Luque (2006) as $M$. ventrosicula, parasitizing E. alletteratus and Sarda sarda (Bloch, 1793).

Family Hexostomatidae Price, 1936

Hexostoma Rafinesque, 1815

\section{Hexostoma albsmithi Dollfus, 1962}

Host: T. obesus (new host record).

Site: Gill

Prevalence: $5.7 \%$

Mean intensity: $16.5 \pm 30.38$

Material studied: $\mathrm{CHIOC}_{37056} \mathrm{a}-\mathrm{j}$

Main measurements (based on 10 adult specimens): Body elongated, tapered anteriorly 9.24-17 (14.2) $\mathrm{mm}$ $\times 2.30-3.50(2.80) \mathrm{mm}$, containing two small suckers 40-62 (51) × 30-47 (40); pharynx 65-110 (86) × 40-87 (66). Intestinal caeca form network of thin canals in dorsal and ventral region of the body. Numerous testes, $60-80$ in number. Ovary located in the middle portion of the body. Vagina 100-160 (133) × 95-150 (116). Vitelline follicles dispersed throughout the body, except in the anterior region and the haptor region. Haptor 3.30-5.70 (4.40) $\mathrm{mm}$ long, containing 4 pairs of oval clamps: 3 larger pairs with similar size, 420-610 (520) × 370-540 (450), including a delicate membrane that surrounds the 
clamps, measuring 35-62 (43) wide; one pair of clamps median, 130-250 (207) × 120-260 (170) including the membrane that measures 20-40 (28). Each clamp present 3 muscular sclerites: 2 lateral small sclerites and one median sclerite X-shaped, with 3-6 perforations. Two pairs of similar anchors: one pair 72-96 (87) long and one small pair 15-38 (21) long. Eggs 200-275 (233) $\times$ 95-175 (131), with two polar filaments: opercular filament, 100-155 (130) long and posterior filament, 105-162 (148) long. Uterus containing 2-16 eggs.

Remarks: Hexostoma albsmithi was described by Dollfus (1962) from gills of the Thunnus thynnus (Linnaeus, 1758) (as Thynnus saliens) from California, Pacific Ocean. In this paper, this specie is reported by the first time from Brazil, Southwestern Atlantic Ocean and in a new host record T. obesus.

\section{Hexostoma euthynni Meserve, 1938}

Synonyms: Hexostoma macracanthum Fujii, 1944; Neohexostoma euthynni (Meserve, 1938) Price, 1961; Neohexostoma kawakawa Yamaguti, 1968; Neohexostoma pricei (Koratha, 1955) Price, 1961

Hosts: A. thazard and E. alletteratus

Site: Gills

Prevalence: A. thazard (25\%); E. alletteratus (16.1\%)

Mean intensity: A. thazard (1.4 \pm 0.51$) ;$ E. alletteratus $(4.8 \pm 3.64)$

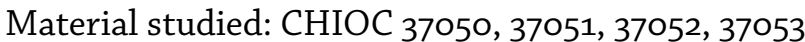

Main measurements (based on four adult specimens): Body elongate, 4.3-7.3 (6.1) $\mathrm{mm} \times 1.2-1.5$ (1.3) $\mathrm{mm}$, presenting a constriction in pretesticular region, tapering from level of ovary to anterior end. Haptor continuous with body proper, each side with four sessile clamps decreasing in size; clamps of uniform structure suckerlike, larger clamps 190-350 (303) × 160-250 (210) and smaller clamps 175-245 (214) × 165-175 (167); each clamp encloses three sclerites, the middle one X-shaped, while the two lateral ones are straight; one pair of large and one pair of small terminal hooks. Two buccal elliptical suckers, 40 and $47 \times 35$; small pharynx; short esophagus bifurcating anterior to genital pore. Genital pore ventral, median. Testes post-ovarian, 22-26 in number. Ovary median, U-shaped. Vagina opens dorsal, 75-90 (82) $\times$ 6o-87 (71), immediately posterior to genital atrium, provided with pair of denticulate bodies. Vitelline consist of irregular follicles. Uterus near midline of body. Eggs fusiform, 200-26o (220) × 100-180 (130) [n=3], with one filament at each pole, measuring 150-230 long.

Remarks: Hexostoma euthynni was described by Meserve (1938) from the gills of E. alletteratus from Galapagos Island, Pacific Ocean. It was also referred from the same ocean as $H$. macracanthum by Fujii (1944) from $E$. alletteratus; as Neohexostoma pricei by Koratha (1955) from Sarda sarda and as N. euthynni from A. thazard and E. affinis by Mamaev (1968). H. euthynni was redescribed from Euthynnus lineatus Kishinouye, 1920 from Pacific Ocean by Millemann (1956), who considered H. macracanthum as synonym. In 1978, Rohde studied this species from Euthynnus alletteratus affinis (Cantor, 1849) from Australia and considered Neohexostoma synonymous of Hexostoma. In the Atlantic Ocean this species was referred by Williams Jr. and Bunkley-Williams (1996) and by Alves and Luque (2006) from gills of E. alletteratus in the genus Neohexostoma.

\section{Hexostoma keokeo Yamaguti, 1968}

Host: A. thazard

Site: Gills

Prevalence: $15 \%$

Mean intensity: $1.33 \pm 0.70$

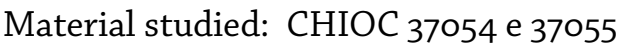

Main measurements (based on two adult specimens): Body elongate, anterior region tapered, 3.6 and $5.7 \mathrm{~mm}$; greatest at width ovary level, 1.1 and $2.2 \mathrm{~mm}$. Haptor papillate, 1 and $1.8 \mathrm{~mm}$, with two lateral papillate lobes; four pairs of clamps 210-225 (217) × 160-230 (195), arranged horizontally, similar, sessile, sucker-like, each clamp presenting three sclerites enclosed in two muscular and oval bands. Two pairs of terminal anchors, outer anchors large, 110 long. Mouth subterminal, surrounded by spherical buccal suckers, $35 \times 37$. Pharynx small, esophagus long, caeca with lateral diverticula reaching to haptor. Testes 18 in number, post-ovarian. Bulbous muscular cirrus. Ovary anterior to mid half of body, U-shaped. Vitelline follicular. Vagina with two symmetrical elongate pads densely covered with conical teeth, 75 and $100 \times 60$ and 9o. Uterus midventral. Egg fusiform $200 \times 90$, filaments on each pole, equal in size, 192 long.

Remarks: Hexostoma keokeo was described by Yamaguti (1968) from gills of A. thazard off Hawaii, Pacific Ocean. In 1995, Murugesh proposed that $H$. keokeo should be considered a synonym of Hexostoma auxisi Palombi, 1943. However, Mogrovejo et al. (2004), based on scanning electron microscopy studies of specimens of $H$. keokeo from Rio de Janeiro coast, did not considered the validity of the synonymy.

\section{Hexostoma sibi Yamaguti, 1968}

Hosts: T. albacares and T. obesus

Site: Gills

Prevalence: T. albacares (10.5\%); T. obesus (22.9\%)

Mean intensity: T. albacares (5.00 \pm 3.39$) ;$ T. obesus

\section{(12.75 44.44$)$}

Material studied: CHIOC 37040, 37041, 37042, 37043, 37044, 37045, 37046, 37047, 37048, 37049

Main measurements (based on ten adult specimens): Body 15.2-22.4 (18.2) $\mathrm{mm} \times$ 4.1-6.4 (5.6) $\mathrm{mm}$, divided into four regions of different width: the first region is very narrow and pointed, 80-170 (125) in the greatest 
width, comprising a pair of cephalic suckers, 38-50 (44) $\times 28-50(36)$, pharynx and anterior part of esophagus. The second region is nearly uniform in width, between the first region and the genital pore, 210-500 (400) wide; the third region occupies the greater middle portion of the body; the fourth region comprises the haptor, 4.1-6.1 (5.2) $\mathrm{mm}$ wide, with four pairs of ventral haptoral suckers: three major pairs, 520-79o (650) × 480-630 (540) and two small pairs 200-330 (270) $\times 200-220(210)$; two pairs of median external anchors, 70-100 (82) long and two pairs of median internal anchors 20-40 (23) long. Testes rounded, 110 in number. Ovary tubular. Vitelline follicles extend along from region of intestinal bifurcation to constriction, between third and fourth region. Eggs oval to elliptical, 200-250 (220) $\times$ 80-190 (130) [ $n=10$ ]; filament, $110-170$ (140) of opercular pole and 110-210 (160) long of opposite pole.

Remarks: Hexostoma sibi was originally described by Yamaguti (1968) from the gills of T. albacares (as $N$. macropterus), T. obesus (as P. sibi) and T. alalunga from Hawaii, Pacific Ocean. In this opportunity this species is referred by the by the first time in Brazil, Southwestern Atlantic Ocean.

\section{ACKNOWLEDGEMENTS}

Finnacial support to Anna Kohn, Research fellow: Conselho Nacional de Desenvolvimento Científico e Tecnológico, CNPq.

\section{LITERATURE CITED}

Abdallah, V.D., J.L. Luque, D.R. Alves and A.R. Paraguassu. 2002. Quantitative aspects of the infrapopulations of metazoan parasites of chub mackerel (Scomber japonicus) (Osteichthyes: Scombridae), from the coastal zone of the state of Rio de Janeiro, Brazil. Revista da Universidade Rural, Série Ciências da vida 22 103-107.

Alves, D.R. and J.L. Luque. 2006. Ecologia das comunidades parasitárias de cinco espécies de escombrídeos (Perciformes: Scombridae) do litoral do Estado do Rio de Janeiro, Brasil. Revista Brasileira de Parasitologia Veterinária 15: 167-181.

Bussiéras, J. 1972. Les Monogénes Capsalinae parasites de thons de l'Atlantic tropical oriental. Annales de Parasitologie 47(1): 29-49.

Bussiéras, J. and F. Baudin-Laurencin. 1967. Caballerocotyla klawei Stunkard 1962 monogéne parasites des sacs nasaux du thon albacore ded l'ocean Atlantique. Revue d'Élevage et de Médecine Vétérinaire des Pays Tropicaux 20(1): 105-108.

Bussiéras, J. and F. Baudin-Laurencin. 1970. Caballerocotyla abidjani n. sp. (Monogenea, Capsalidae), parasite des opercules du thon albacore, Thunnus albacares. ORSTOM, Serie Océanografica 8(3): 47-51.

Bussiéras, J. and F. Baudin-Laurencin. 1973. Les hélminthes parasites dês thons tropicaux. Revue d'Élevage et de Médicine Vétérinaire des Tropicaux 26: 13-19.

Chisholm, L.A. and I.A. Whittington. 2007. Review of the Capsalinae (Monogenea: Capsalidae). Zootaxa 1559: 1-30.

Cohen, S.C., M.C. Justo and A. Kohn. 2013. South American Monogenoidea parasites of fishes, amphibians and reptiles. Rio de Janeiro: Oficina de livros. 663 pp.

Collette, B.B. and C.E. Nauen. 1983. FAO Species Catalogue. Vol. 2. Scombrids of the World. An annotated and illustrated catalogue of tunas, mackerels, bonitos and related species know to date. FAO Fisheries Synopses. 137 p.

Dollfus, R.P. 1962. Deux especes de trematodes monogenetiques parasites du Bluefin Tuna de California. Annales de Parasitologie Humanie et Comparée 37(4): 517-529.

Egorova, T.P. 200o. Occurrence of Monogenea of the superfamily Capsalinae (Capsalidae) parasites of marine fishes. Parazitologiya 34: 111-117. [In Russian].

Fujii, H. 1944. Three monogenetic trematodes from marine fishes. Journal of Parasitology 30: 153-158.

Ishii, N. 1936. Some new trematodes of marine fishes. Zoological Magazine 48:781-787. [In Japanese].

Kohn, A. and M.C.N. Justo. 2006. Caballerocotyla llewelyni n. sp. and Caballerocotyla neothunni (Yamaguti, 1968) (Monogenea; Capsalidae) parasites of Brazilian tunas (Scombridae). Zootaxa 1139: 19-26.

Kohn, A., A.L. Santos and S.C. Cohen. 2003. Report of two parasites from brazilian tunas. Arquivos de Ciências do Mar 36: 19-22.

Kohn, A., M.F.D. Baptista-Farias, A.L. Santos and D.I. Gibson. 2004. A new species of Nasicola Yamaguti, 1968 (Monogenea, Capsaliae) from the nasal cavities of Thunnus obesus and redescription of $N$. klawei (Stunkard, 1962) from T. albacares off Brazil. Systematic Parasitology 57(1): 51-58. doi: 10.1023/B:SYPA.0000010685.918 91.5e

Koratha, K.J. 1955. Studies on the monogenetic trematodes of the Texas coast. II. Descriptions of species from marine fishes of Port Aransas. Institute Marine Sciences University of Texas 4(1): 251-278.

Mamaev, Yu.L. 1968. Helminths of tuna fish in the South China Sea; pp. 5-27, in: K.I. Skryabin and Yu.L. Mamaev. Helminths of animals of the Pacific Ocean. Moscow, Nauka. [In Russian].

Meserve, F.G. 1938. Some monogenetic trematodes from the Galapagos Islands and the neighboring Pacific. Reports of the Allan Hancock Pacific Expeditions (1932-1937) 2: 31-89.

Millemann, R.E. 1956. Notes on the genus Hexostoma (Monogenea: Hexostomatidae) with a redescription of $H$. euthynni Meserve, 1938. Journal Parasitology 42: 316-319.

Mogrovejo, D.C. and C.P. Santos. 2002. Caballerocotyla lenti n. sp., a Capsalid Monogenea from Auxis thazard (Scombridae) from off the Southeastern Coast of Brazil. Memórias do Instituto Oswaldo Cruz 97(7): 1067-1071. doi: 10.1590/So074-02762002000700023

Mogrovejo, D.C., H. Lent and C.P. Santos. 2004. Morphological aspects of marine Monogenea (Platyhelminths) parasitic on the gills of Auxis thazard (Lacèpede) (Scombridae) from Rio de Janeiro, Brazil. Revista Brasileira de Zoologia 1(2): 201-206. doi: 10.1590/So074-02762002000700023

Murugesh, M. 1995. Monogenetic trematodes from scombrid fishes of the Visakhapatnam coast, Bay of Bengal. Journal of Natural History 9: 1-26.

Oliva, M.E., I.M.Valdivia, G. Costa, N. Freitas, M.A. Pinheiro de Carvalho, L. Sánchez and J.L Luque. 2008. Why can metazoan parasites reveal about the taxonomy of Scomber japonicus Houttuyn in the coast of South America and Madeira Islands. Journal of Fish Biology 72: 545-554.

Price, E.W. 1938. The monogenetic trematodes of Latin America; pp. 207-413, in: Livro Jubilar Prof. Travassos. Rio de Janeiro: Instituto Oswaldo Cruz.

Price, E.W. 1960. The giant marlin, Makiara marlina Jordan and Evermann, a new host for Capsala pricei Hidalgo, 1959, with a review of the subfamily Capsalinae; pp. 237-244, in: Libro Homenaje al Doctor Eduardo Caballero y Caballero, Jubileo 1930-1960. Instituto Politécnico Nacional, Escuela Nacional de Ciencias Biológicas México.

Rego, A.A., and C.P Santos. 1983. Helmintofauna de cavalas, Scomber japonicus Hiutt, do Rio de Janeiro. Memórias do Instituto Oswaldo Cruz 78: 443-448. 
Rohde, K. 1978. Monogenea of Australian Marine fishes. The genera Dionchus, Sibitrema and Hexostoma. Publications of the Seto Marine Biological Laboratory 24: 349-367.

Rohde, K. 1986. Grubea australis n. sp. (Monogenea, Polyopisthocotylea) from Scomber australasicus in southeastern Australia, and Grubea cochlear Diesing, 1858 from S. scombrus and S. japonicus in the Mediterranean and western Atlantic. Systematic Parasitology 9:29-38. doi: 10.1007/BFoooog894

Rohde, K., and C. Hayward. 1999. Revision of the Monogenea subfamily Priceinae Chauhan, 1953 (Polyopisthocotylea: Thoracocotylidae). Systematic Parasitology 44(3): 171-182. doi: 10.1023/A:1006288730216

Rohde, K., and N. Watson. 1985. Morphology, microhabitats and geographic variation of Kuhnia spp. (Monogenea: Polyopisthocotylea). International Journal of Parasitology 15 (5): 569-586. doi: 10.1016/0020-7519(85)90054-2

Stunkard, H.W. 1962. Caballerocotyla klawei sp. n., a monogenetic trematode from nasal capsule of Neothunnus macropterus.
Journal of Parasitology 48: 883-89. doi: 10.2307/3275120

Williams, Jr. E., and L. Bunkley-Williams. 1996. Parasites of offshore big game fishes of Puerto Rico and the Western Atlantic. Antillean College Press. 382 pp.

Yamaguti, S. 1965. New monogenetic trematodes from Hawaiian fishes, I. Pacific Science 19(1): 55-95.

Yamaguti, S. 1966. New monogenetic trematodes from Hawaiian fishes, II. Pacific Science 20: 419-434.

Yamaguti, S. 1968. Monogenetic trematodes from Hawaiian fishes. University of Hawaii, Press. 288 pp.

Authors' contribution statement: Both authors collected the material, identified all species and wrote the text.

Received: December 2014

Accepted: March 2015

Editorial responsibility: Simone Chinicz Cohen 